УДК 340.0

DOI https://doi.org/10.32837/pyuv.v1i3(28).344

\author{
М.О. Пащенко \\ аспірантка кафедри теорії права та держави \\ юридичного факультету \\ Київського національного університету імені Тараса Шевченка
}

\title{
ПРАВОВЕ РЕГУЛЮВАННЯ ЗАХИСТУ ПРИРОДНИХ ПРАВ ЛЮДИНИ: СТАН ТА ШЛЯХИ ВДОСКОНАЛЕННЯ
}

Постановка проблеми. Правове регулювання захисту природних прав людини є необхідною складовою частиною сучасної правової держави, оскільки саме вона бере на себе обов'язок визнання та правового регулювання природних прав людини, особливо їх захисту, поєднуючи, таким чином, три загальнолюдські цінності - природні права людини, їх захист та правову державу. Ідея єдності вищеназваних цінностей закріплена в пункті 2 Документа Копенгагенської наради Конференції з людського виміру Організації з безпеки і співробітництва в Європі 1990 року, в якому зафіксовано, що правова держава є не просто формальною законністю, яка забезпечує регулярність і послідовність у досягненні і підтримці демократичного порядку, а і справедливістю, заснованою на визнанні і повному прийнятті вищої цінності людської особистості, гарантованої інституціями, що утворюють структури, які забезпечують її найбільш повний вираз [1, с. 1].

Українська правова система потребує суттєвої переорієнтації всього законодавства, всієї системи правового регулювання з метою забезпечення визнання, формування поваги і реалізації захисту природних прав людини. У зв'язку із цим виникає потреба у формуванні та осмисленні особливостей правового регулювання захисту природних прав людини. Сучасне правове регулювання захисту природних прав людини - явище нове у вітчизняній теорії права, що становить актуальну науково-теоретичну проблему.

Стан дослідження. За останні роки у юридичній літературі проблемам особливостей правового регулювання захисту природних прав людини приділяється все більше уваги. Концептуальним питанням аналізу правового регулювання правозахисних відносин щодо невід'ємних прав людини в контексті міжнародних норм регулювання природних прав людини присвячені роботи таких зарубіжних вчених, як: М. Дженіс, Р. Макдональда, Д. Шелта. Серед вітчизняних науковців, які досліджують цю проблему, можливо назвати А.М. Колодія, П.М. Рабіновича, М.I. Козюбру, О.В. Петришина.

Метою цієї публікації є теоретико-правове дослідження правового регулювання захисту природних прав людини шляхом виокремлення особливостей внутрішньодержавного і міжнародно-правового регулювання захисту природних прав людини. Досягнення означеної мети потребує вирішення таких завдань: а) охарактеризувати правове регулювання правозахисних відносин внутрішньодержавного і міжнародного правового регулювання і визначити перспективи вдосконалення українського законодавства у сфері захисту природних прав людини; б) дослідити основні міжнародно-правові та внутрішньодержавні нормативно-правові акти, що регулюють особливості захисту природних прав людини; в) проаналізувати проблемні питання, пов'язані 3 необхідністю захисту природних прав людини у сучасним умовах.

Правове регулювання означеної наукової проблеми в юридичній літературі називають особливими правовідносинами [2, с. 48], оскільки останні:

1) виникають на підставі такого явища, як право людини на захист її природних прав. Це право породжує правозахисне ставлення незалежно від того, зафіксовано воно в національному законодавстві чи ні. У будь-якому випадку людина має право самостійно і за допомогою інших суб'єктів захищати свої невід'ємні права, ініціюючи здійснення в межах цих відносин правозахисних повноважень як внутрішньодержавних, так і міжнародних правозахисних органів і організацій;

2) характеризуються юридичним зв'язком сторін, де правомочна сторона - людина як суб'єкт права на правовий захист - покладає відповідний юридичний обов'язок на іншу;

3) здійснюють права людини на правовий захист іï природних прав і виконання пов'язаного 3 ним юридичного обов'язку, забезпечують можливість державного і міжнародного примусу, але можуть бути реалізовані і без втручання правозахисних органів і організацій.

Істотне значення у правовому регулюванні захисту природних прав людини мають суспільні відносини, у яких, по-перше, складаються первинні (загальні) приписи (зобов'язання, дозвіл і заборони), що виражають природно-соціальну основу потреби людини на захист її природних і духовних якостей, по-друге - формується правозахисна спрямованість регулятивного впливу усього набору правових засобів - інструменталь- 
ного оснащення реалізації правового регулювання означеної наукової проблеми.

Такі правовідносини не лише зумовлюють правове регулювання захисту природних прав людини, а й виокремлюють його серед всіх інших способів правового регулювання.

Особливість правового регулювання захисту природних прав людини полягає в характеристиці тих закономірностей, у межах яких воно здійснюється:

1) набуття людиною права на правовий захист ïi природних прав як юридично можливого і гарантованого варіанту поведінки у випадках створення перешкод для реалізації означених прав, загрози їх порушення або фактичного порушення;

2) закріплення та покладання на людину юридичних обов'язків, кореспондуючих із правом людини на правовий захист її невід'ємних прав, у тому числі встановлення і застосування заходів державного або громадського впливу за порушення захисту природних прав людини.

Сутність правового регулювання захисту природних прав людини матеріалізується у змісті дії захисту, що має структуру, яка здійснює поетапне регулювання впливу на поведінку людей:

1) першим етапом правового регулювання захисту природних прав людини є міжнародне та внутрішньодержавне визнання природних прав людини на правовий захист;

2) другим етапом є визначення підстав виникнення, зміни і припинення відповідних правовідносин. Необхідність встановлення цих підстав полягає в тому, що:

1) поза і крім правозахисних відносин, право людини на правовий захист її невід'ємних прав не може бути реалізовано;

2) підстави виникнення, припинення і зміни правозахисних відносин виступають тими юридичними фактами, що забезпечують їхню динаміку, отже, і динаміку юридичних зв'язків (прав і обов'язків) суб'єктів - сторін правовідносин. А юридичні факти, зумовлюючи виникнення, зміни та припинення правозахисних відносин, є підставами виникнення динамічних процесів у статусах та юридичних зв' язках суб'єктів цих відносин.

Юридичні джерела містять поділ правового регулювання захисту природних прав людини на міжнародно-правове регулювання захисту природних прав людини та внутрішньодержавне правове регулювання захисту природних прав людини [3, с. 56].

У межах міжнародно-правового регулювання захист природних прав людини є частиною міжнародного права, оскільки вирішення означеної наукової проблеми здійснюється шляхом міжнародного контролю, що залежить від стану дотримання країною основних умов захисту природних прав людини, що регулюються:
1) міжнародно-правовими актами, які містять правила діяльності, формулюють права та обов'язки відповідних суб'єктів (конвенції, пакти, угоди, договори), а також міжнародними документами, що не містять норми, правила поведінки, що безпосередньо не формулюють права і обов'язки (декларації, заяви, меморандуми);

2) міжнародними органами спостереження, контролю за дотриманням невід'ємних прав людини (комісії, комітети) та захисту цих прав (суди, трибунали) [4, с. 234].

К. Слюсар обгрунтовує, що визнання державою природних прав людини шляхом закріплення їх у Конституції та інших законодавчих актах розглядається лише як перший крок до їх затвердження і реалізації. Вчений доводить, що обсяг прав людини, закріплений у міжнародних документах, регулюючих природні права людини, виконує роль взірця, до якого повинні прагнути всі суспільства й держави сучасного політико-правового світу. А міжнародні стандарти у сфері природних прав людини є підставою для міждержавного співробітництва з питань їх забезпечення для діяльності спеціальних міжнародних органів зі спостереження за дотриманням і захистом прав людини [4, с. 236]

На думку П. Маланчука, має місце поділ основних форм впливу міжнародних правозахисних норм, що регулюють природні права людини, а також принципи їх впливу на внутрішньодержавне право, а саме:

1) вплив у процесі імплементації міжнародних норм і принципів у сфері захисту природних прав людини;

2) вплив під час усунення невідповідностей українських правозахисних норм міжнародним у сфері захисту природних прав людини;

3) вплив і облік під час розроблення правозахисного законодавства у сфері захисту природних прав людини [5, с. 298]

Томас Погге доводить, що вплив міжнародного права на внутрішньодержавну правову систему закріплений у статті 28 Загальної Декларації прав людини, яка містить вимогу, відповідно до якої глобальна система інститутів держави повинна бути оцінена і реформована в аспекті їі відносного вкладу в реалізацію прав людини. Ця глобальна вимога, на думку вченого, свідчить про те, що права людини в інституційній сфері мають нормативне значення у світовому масштабі, оскільки права, якими наділена кожна людина, передбачають моральні та правові вимоги не лише до соціальних інститутів, але і до їі власного суспільства та всіх ïi співгромадян, і ті ж самі вимоги стоять перед глобальним устроєм суспільства, а отже, мають відношення і до всіх людей взагалі [6, с. 286].

Міжнародно-правове регулювання захисту природних прав людини здійснюється на осно- 
ві міжнародних норм і принципів, що містяться в конвенціях, деклараціях, пактах, міжнародних договорах та інших міжнародних актах. Міжнародні правові акти класифікуються вченими (М.В. Цвік, О.М. Шпакович) за територіальною ознакою та поділяються на універсальні і регіональні акти [7, с. 105].

Універсальні міжнародно-правові акти діють для країн, що належать до різних територій нашої планети, до різних правових систем, виконуючи головну регулятивну роль у правовому регулюванні правозахисної діяльності природних прав людини, серед яких провідна роль належить таким трьом основним документам, як:

1) Статут Організації Об’єднаних Націй, що був підписаний 26 червня 1945 року в місті Сан-Франциско після закінчення Конференції Організації Об'єднаних Націй та набрав чинності 24 жовтня 1945 р. [8, с. 1], є одним із провідних документів міжнародного значення, який містить правові основи регулювання захисту природних прав людини. Створення Організації Об’єднаних Націй (надалі по тексту - ООН) і прийняття Статуту ООН науковці одноголосно розцінюють як основний етап у формуванні правового регулювання захисту природних прав людини у зв'язку з тим, що останній містить становлення принципу поваги до прав людини, оскільки у Статуті ООН уперше отримав закріплення принцип загальної поваги до прав людини без будь-якої дискримінації [8, с. 3];

2) Загальна декларація із прав і свобод людини 1948 року є значущим документом серед міжнародних актів, що здійснює регулювання захисту природних прав людини. Відповідно до статті 1 зазначеної Декларації основним елементом для визнання природних прав людини є гідність людини, що кваліфікується як невід'ємна властивість, яка притаманна кожній людині від народження, визначає рівність її прав і свобод, поводження у відношенні однієї людини до іншої в дусі братерства [9, с. 1]. Рівність прав і свобод означає, що кожна людина повинна володіти ними незалежно від раси, статі, мови, релігії, політичних переконань, соціального стану, національності, проживання на території незалежної держави, або на підопічній чи території без самоврядування (ст. 2). Деякі вчені надають Загальній декларації прав людини головну роль у регулюванні захисту природних прав людини. Так, А.I. Забайло зазначає, що Загальна декларація прав і свобод людини є першим універсальним міжнародним правовим актом, яким державами світової спільноти погоджено, систематизовано і проголошено основні права і свободи, що повинні бути надані кожній людині на Землі [10, с. 66]. Вчений обгрунтовує, що Декларація стала першим документом у комплексі універсальних міжнародних актів загального характеру у сфері прав людини [10, с 67]. Не- зважаючи на те, що в Загальній декларації прав людини було викладено досить широкий, хоч і неповний перелік норм про природні права людини, в зазначеному документі вперше були закріплені такі основні права, як: право на свободу, рівність, справедливість, право на життя та ін. А частина 2 статті 27 Загальної декларації прав людини містить основну правозахисну норму, згідно 3 якою кожна людина має право на захист її моральних і матеріальних інтересів [10, с. 69].

Є.В. Ревіна доводить, що Загальна декларація $€$ тією основою, на якій уже майже 50 років здійснюється правове регулювання у сфері захисту природних прав людини [11, с. 120];

3) Міжнародний білль про права людини - міжнародно-правовий акт, що складається із: а) Загальної декларації прав і свобод людини 1948 року, б) Міжнародного пакту про громадянські і політичні права (із його двома факультативними протоколами), в) Міжнародного пакту про економічні, соціальні і культурні права, що є загальним постулатом серед міжнародно-правових актів, що регулюють захист природних прав людини. Значення Міжнародного білля про права людини є вагомим, оскільки прийняття зазначеної сукупності актів вплинуло на розуміння природних прав людини майже всіма державами (їх урядами) світу. Міжнародний білль про права людини закріплює важливий перелік основних прав людини, їх захисту, що охоплює всі аспекти життя людини [12, с. 403].

Означені вище міжнародно-правові акти стали основою для прийняття міжнародних документів про права людини - пактів, інших угод з окремих проблем прав людини, що стали кодексами, які визначають та регулюють основні принципи і норми у сфері природних прав людини та забезпечення їх захисту на міжнародній арені.

Регіональні міжнародно-правові акти є правовими документами, прийнятими регіональними міжнародними організаціями, такими як: Рада Європи, Співдружність Незалежних Держав, Нарада з безпеки і співробітництва у Свропі. Регіональні міжнародно-правові акти діють у межах певного регіону земної кулі (Європа, Америка, Африка і т.п.).

Характеристика змісту означених вище міжнародних документів не складає предмету нашого дослідження, однак їх перелік надає можливість зробити висновок про достатню розгалуженість правового регулювання захисту природних прав на міжнародному рівні, що забезпечує:

1) виокремлення різноманітних природних прав людини;

2) визначення засобів впливу як гарантій їх захисту;

3) забезпечення єдності процесу захисту цих прав; 
4) виокремлення ролі різноманітних міжнародних органів та організацій, спеціально створених державами для такого захисту;

5) узгодження волі різноманітних держав у сфері захисту природних прав людини та вироблення єдиної правозахисної політики. Огляд міжнародних документів надає можливість обгрунтувати теоретичні висновки щодо їх впливу на нормативний рівень національного правового регулювання захисту природних прав людини. Саме ці нормативно-правові акти:

1) складають міжнародні стандарти правового регулювання захисту прав людини;

2) визначають принципи захисту цих прав;

3) імплементуються в національне законодавство;

4) конкретизуються національним законодавством із метою врахування особливостей певної держави;

5) визначають обов'язки держави у цій сфері;

6) забезпечують можливість реалізації захисту прав у випадку неефективності національного законодавства;

7) визначають рівень ефективності правозахисного законодавства певної держави;

8) зумовлюють обов'язок держави щодо вдосконалення правового регулювання у сфері захисту природних прав;

9) визначають форми можливої відповідальності держави за перешкоди захисту природних прав людини;

10) визначають межі правового впливу держави у сфері захисту цих прав;

11) передбачають засоби та способи міжнародно-правового впливу на держави, які не забезпечують ефективний захист природних прав людини;

12) формують можливості застосування міжнародних гарантій відновлення порушених прав.

У зв'язку з вищевикладеним ми можемо обІрунтувати, що міжнародно-правове регулювання у сфері захисту природних прав людини здійснює вирішальний вплив на внутрішньодержавне законодавство і практику його застосування в найрізноманітніших сферах, пов'язаних із захистом природних прав людини. Зокрема, останній виявляється в імплементації міжнародних принципів, норм у внутрішньодержавне право (шляхом ратифікації міжнародних договорів), в усуненні невідповідності норм українського права міжнародним правилам і стандартам, а також в обліку норм міжнародного права під час розроблення вітчизняних нормативно-правових актів.

Внутрішньодержавне правове регулювання захисту природних прав людини є сукупністю спеціальних юридичних засобів результативного впливу, здійснюваних державою за допомогою права i сукупності правових засобів, їх юридичного закрі- плення, охорони і розвитку. Внутрішньодержавне правове регулювання захисту природних прав людини здійснюється державою через використання права (нормативне регулювання) та влади.

Внутрішньодержавне правове регулювання захисту природних прав людини є:

- по-перше, обов'язком держави, у зв'язку із чим усі органи державної влади зобов'язані перш за все виконувати означений обов'язок;

- по-друге, означений обов'язок гарантується Конституцією як основним законом держави;

- по-трете, Конституція містить перелік суб'єктів права (органів влади), які зобов'язані здійснювати захист природних прав людини від імені держави.

Отже, внутрішньодержавне правове регулювання захисту природних прав людини здійснюється на підставі основного закону держави - Конституції та інших нормативно-правових актів.

М.Г. Хаустова обгрунтовує, що основним документом, який регулює право людини на захист у тому числі і їі природних прав, є Конституції України, у якій закріплено (ч. 6 ст. 55), що кожен має право будь-якими не забороненими законом засобами захищати свої права і свободи від порушень і протиправних посягань [13, с. 44]. Науковець доводить, що законодавець закріплює на конституційному рівні абстрактно-загальне визначення цього права, передбачаючи його деталізацію на інших рівнях правового регулювання, відповідно до суспільно-правових відносин, в яких воно безпосередньо реалізується [13, с. 44 ].

В.М. Радь поділяє захист природних прав людини на:

1) юридичний захист - захист, що здійснюється за різними напрямами його реалізації відповідно до галузей права. Юридичний захист вчений класифікує за суб'єктом захисту, де виокремлює такі категорії: а) самозахист; б) судовий; в) захист, що здійснюється Уповноваженим із прав людини; г) захист Конституційним судом (на підставі конституційної скарги); д) захист, що здійснюється відповідними міжнародними суб'єктами (міжнародними судовими установами чи відповідними органами міжнародних організацій);

2) фактичний захист - захист, що здійснюється у формі відповідних фактичних діянь у певних суспільних відносинах [14, с. 238].

Висновки. Виходячи з вищевикладеного, ми можемо зробити висновок, що:

1) наявне міжнародно-правове регулювання $€$ підставою для здійснення ефективного правового регулювання захисту природних прав людини;

2) акти органів міжнародних організацій, як i міжнародне право у цілому, впливають на процес створення нормативних актів щодо захисту природних прав людини в національних правових системах та на їх застосування; 
3) внутрішньодержавне законодавство містить обмеження природних прав людини та потребує приведення у відповідність до міжнародних стандартів і конституційних приписів;

4) головним питанням проблеми правопорушення природних прав людини у сучасних умовах $є$ антиконституційні обмеження природних прав людини.

\section{Jimepamypa}

1. Документ Копенгагенської наради Конференціі з людського виміру Організації з безпеки і співробітництва в Європі 1990 p. URL : https://zakon.rada.gov.ua/ laws/show/994 082.

2. Гриб В.В. Правовые основы правозащитной деятельности на международном и федеральном уровне. Журнал Юридическая наука и практика: Вестник Нижегородской академии МВД России. 2018. Вып. 4(44). С. 48-52.

3. Антонович М.М. Співвідношення міжнародних та внутрішньодержавних механізмів забезпечення прав людини. Наукові записки. НаУКМА. Том 10. Київ, 2000.

4. Слюсар К. Закріплення поколінь прав людини в міжнародних документах. Підприємство господар ствоправо.Теоріядержавиі права.12/2017.С. 234-238.

5. Маланчук П. Вступ до міжнародного права за Ейкхерстом. Харків : Консум, 2000. 592 с.

6. Філософія прав людини / За редакцією Штефана Госепата та Георга Ломанна. Київ : Ніка-Центр, 2012. C. $286,295$.

7. Шпакович О.М. Вплив актів міжнародних організацій на внутрішні порядки держав-членів. Акту альні проблеми міжнародних відносин. Випуск 101 (Частина I), 2011. С. 105-109.

8. Статут OOH (1945 p.). URL:http://www.un.org.ua/ images/UN_Charter_Ukrainian.pdf.

9. Фаткуллин Ф.Н. Проблемы теории государства и права : курс лекций. Казань : Изд-во Казан. ун-та, $1987.334 \mathrm{c}$

10. Забайло А.И. К вопросу о правовом статусе Всеобщей декларации прав человека и ее влиянии на правотворческий и правоприменительный процессы. Журнал международного права и международных отношений. 2008. № 4. С. 67-69.

11. Ревина Е.В. Правозащитные отношения: теоретико-правовые аспекты : дис. ... канд. юрид. наук. Саранск, 2008.

12. Право международных организаций : учебник / Под ред. И.П. Блищенко, А.Х. Абашидзе. Москва : РУДН, 2013. $489 \mathrm{c.}$

13. Хаустова М.Г. Міжнародні стандарти в контексті євроінтеграційних процесів в Україні. Вісник на иіональної академії правових наук України. № 2(89). 2017. C. $43-51$.
14. Радь В.М. Щодо питання місця права на захист у системі прав людини. Євроатлантична інтеграція України: свідомий вибір моделі безпеки : зб. наук. ст. за матеріалами III Харків. міжнар.-прав. читань, присвяч. пам'яті проф. М.В. Яновського і В.С. Семенова, м. Харків, 3 листоп. 2017 р. : у 2 ч. Харків, 2017. Ч. 2. C. 238-242.

\section{Анотація}

Пащенко М. О. Правове регулювання захисту природних прав людини: стан та шляхи вдосконалення. Стаття.

Стаття присвячена аналізу особливостей правового регулювання захисту природних прав людини через виокремлення внутрішньодержавного та міжнародно-правового регулювання. Охарактеризовано правове регулювання правозахисних відносин, визначено перспективи вдосконалення українського законодавства у сфері захисту природних прав людини. Досліджено основні міжнародно-правові та внутрішньодержавні нормативно-правові акти, що регулюють особливості захисту природних прав людини. Проаналізовано проблемні питання, пов'язані з необхідністю захисту природних прав людини у сучасних умовах. 3'ясовано особливості правозахисних відносин, що полягають у виникненні на підставі права людини на захист, передбачають юридичний зв'язок сторін, забезпечені можливістю державного примусу. Особливості правового регулювання захисту природних прав розкрито через особливості суспільних відносин, у межах яких воно здійснюється; закономірностей, що характеризують правове регулювання.

Мова йде про набуття людиною права на правовий захист її природних прав як юридично можливого і гарантованого варіанту поведінки за наявності перешкод ïx реалізації та закріплення та покладення юридичних обов'язків, у т.ч. і застосування заходів державного вплив за порушення захисту природних прав людини. 3 огляду на це виокремлено етапи регулювання впливу на поведінку суб'єктів: міжнародне та внутрішньодержавне визнання права на правовий захист; визначення правового захисту; визначення підстав виникнення, зміни і припинення правозахисних відносин.

Особлива увага приділена 3'ясуванню форм впливу міжнародних правозахисних норм, що регулюють природні права людини, та принципів їх впливу на внутрішньодержавне право. В якості основних міжнародно-правових актів регулювання правозахисної діяльності досліджено Статут ООН, Загальну декларацію прав і свобод людини та міжнародний білль про права людини. 3'ясовано значення конвенцій $\mathrm{OOH}$, актів регіональних, міжнародних організацій. Виокремлено особливості внутрішньодержавного правового регулювання захисту природних прав людини.

Ключові слова: правове регулювання, захист природних прав, законодавство, міжнародно-правове регулювання, внутрішньодержавне право, правозахисні відносини, визнання права на захист. 


\section{Summary}

Pashchenko M. O. Legal regulation of the protection of natural human rights: the state and ways of improvement. - Article.

The article is devoted to the analysis of the peculiarities of legal regulation of protection of natural human rights through the separation of domestic and international legal regulation. The article characterizes the legal regulation of human rights relations. It defines the prospects of improvement of the Ukrainian legislation in the sphere of protection of natural human rights. It investigates the first international legal and national legal acts regulating the peculiarities of the protection of natural human rights. Problematic issues related to the need to protect natural human rights in the current context are analyzed. The peculiarities of human rights relations, which are based on the human right to protection, provide the legal connection between the parties, secured by the possibility of state coercion. The peculiarities of the legal regulation of the protection of natural rights are revealed because of the peculiarities of the social relations within which it is exercised laws that characterize legal regulation.

It is about acquiring a person the right to legal protection of his natural rights as legally possible and a guar- anteed variant of behavior in the presence of obstacles to their implementation and securing and laying down legal obligations, and the application of measures of state influence to violate the protection of natural human rights. In this regard, the stages of regulating the influence on the behavior of the subjects are distinguished: international and national recognition of the right to legal protection, the definition of legal protection; determining the grounds for the emergence, change, and termination of human rights relations.

The author pays attention to exploring the forms of influence of international human rights norms governing natural human rights and the principles of their influence on domestic law. The UN Charter, the Universal Declaration of Human Rights and Freedoms, and the International Human Rights Bill have been examined as the main international legal acts regulating human rights activities. The significance of the UN conventions, acts of regional and international organizations has been clarified. The peculiarities of the domestic legal regulation of the protection of natural human rights are distinguished.

Key words: legal regulation, protection of natural rights, legislation, international legal regulation, domestic law, human rights relations, recognition of the right to defense. 